\title{
Reproduction Forms of Sustainable Development Policy in Russia
}

\author{
Sergey Zhironkin ${ }^{1,2, *}$, Juraj Janocko ${ }^{3}$, Svetlana Demchenko ${ }^{1}$, Yulia Suslova ${ }^{1}$ and Olga \\ Zhironkina $^{4}$ \\ ${ }^{1}$ Siberian Federal University, 660075 Lida Prushinskaya St. 2, Krasnoyarsk, Russia \\ ${ }^{2}$ T.F. Gorbachev Kuzbass State Technical University, 650000 Kemerovo, 28 Vesennya st., \\ Kemerovo, Russia \\ ${ }^{3}$ Technical University in Kosice, Institute of Earth Resources, Faculty of Mining, Ecology, Process \\ Control and Geotechnologies, Park Komenského 19, 042000 Košice, Slovakia \\ ${ }^{4}$ Kemerovo State University, 650043, 6 Krasnaya St., Kemerovo, Russia
}

\begin{abstract}
The objective meaning of the sustainable development process in relation to the neo-industrialization of the economy is to create conditions for the restoration of the ecological identity of the national economy as a multi-industry production complex. We consider the neo-industrial development of the economy as the re-establishment of a competitive manufacturing complex in it, capable of saturating the domestic market avoiding increasing the burden on the environment with the innovative development of raw materials production, creating the material basis of national competitiveness in the environmental plan. From sustainable development point of view, neo-industrialization means conducting a comprehensive structural policy, the object of which should be national reproduction, and the subject is deep transformations of the processes that form the complex of human impact on nature, its institutional and technological structure, increasing the reproductive role of the green economy based on the potential of the internal market. At the same time, the history of greening industry, which dates back to the 1990s, testifies to the positive experience of replacing global production chains of raw materials, in particular, energy carriers, with the benefits of a fundamentally new type - alternative energy sources, biomaterials. Therefore, the development of technologically advanced manufacturing industry based on technologies of the green economy is possible as a result of the formation of production of goods and services that are maximally focused on meeting the environmental needs of society.
\end{abstract}

\section{Introduction}

In the context of the analysis of neo-industrial methodology [1-4], based on existing approaches to the analysis of sustainable development, we give its following definition - as the process of creating links in the economy of production of tangible and intangible goods for the domestic market, using a combination of domestic demand potential and incentives

\footnotetext{
*Correspondent author: zhironkinsa@,kuzstu.ru
} 
to accelerate the innovative development of the green economy. In a reproductive spirit, sustainable development means a change in the investment structure with the advent of resource-saving and environment friendly technologies to dominate, with the expansion of the share of green economy sectors, with the development of new interactions between science and production, with the formation of new social groups that can ensure the involvement of human capital in the process of greening the industry on a new technological basis.

That is, we are talking about sustainable development as an integral part of the neoindustrial development of the modern economy, for which drivers of accelerated development of the green economy are unavailable due to objective reasons (growth of natural resources, increase in the number of developing countries and population density in developed countries over the past decades), corresponding to the most modern international environmental standards.

The difference between the sustainable development of the neo-industrial type and the modern expansion of man in nature is manifested at the level of goals that shift from shortterm market to long-term reproduction - creating conditions for sustainable development in the process of deep production and technological diversification, increasing the degree of redistribution of raw materials, creating new jobs in manufacturing and high-tech industries, expanding the green economy.

Another difference between sustainable development and resource-oriented development lies in its subjects. If economic growth due to increased resource consumption is implemented in the state's control system over the economy, and maintaining the growth of raw materials markets requires constant intervention in the market in order to protect against foreign competition, then in the system of sustainable development the companies of the green economy sectors that are partner relations with the state. The environmentally-oriented nature of sustainable development involves the modification of economic relations in the reproductive sphere related to the investment of innovations in the green economy and their transfer to production, with the modernization of production capacities, with increasing the scale of production of environment friendly products for the domestic market and increasing its competitiveness.

\section{Materials and Methods}

The most serious obstacles to sustainable development in Russia lie, in our opinion, in the problems of developing the system of national reproduction, in particular, investing in innovations of the green economy. Today, Russia is seriously delayed integrating into the global sphere of innovative environmental technologies. According to the World Bank Russia in 2010-2014 exported high-tech products worth about \$ 3 billion, which is 5 times less than Thailand, 15 times less than China; the ratio of high-tech exports in Russia to the US level is $2 \%$, Japan and Germany $-3 \%$, France and the UK - 7\% [5]. At the same time, according to the estimates of the United Nations Conference on Trade and Development (UNCTAD) in the last decade, the most successful countries in innovative development and foreign trade expansion were countries where the state pursued an "active" environmental policy [6]. It implies profound changes in the institutional structure and "investment behavior" of corporations, in the technological level of exports. On the contrary, a "passive" industrial policy implies reliance on the raw materials sector and an emphasis on reducing the costs of their production.

Stimulating innovation activity, developing green products in Russia is constrained not only by a lack of investment, but also by a lack of specialists with the required qualifications. According to surveys of company managers conducted by the All-Russian Center for the Study of Public Opinion in 2010-2014, the shortage of highly qualified personnel for 
innovative development is estimated at 1.6 million people, i.e. about $8 \%$ employed in industry. Moreover, in 2010, an average of $6 \%$ of graduates of technical universities cannot find a job in the first two years after graduation, and $17 \%$ do not work in their specialty [7]. Therefore, it is obvious that sustainable development requires changes in the institutional environment for the reproduction of not only industrial capital, but also intellectual capital.

An equally important reproductive problem of sustainable development is the reduction in the ability of the Russian state to invest effectively in manufacturing and high-tech sectors, despite the state's share in the real sector close to the dominant one. So, the share of jointstock companies in the RTS index in 2014 amounted to $51 \%$ (with a maximum of $66 \%$ in 2007) [7]. According the experts from the largest French financial group BNP Paribas, stateowned companies own $45 \%$ of Russian oil production, $49 \%$ of the banking sector, $73 \%$ of transportation (including railway) [8]. According to the Federal State Statistics Service, the share of the public sector in 2014 was $15 \%$ in communication services, $27 \%$ in electricity and heat, $17 \%$ in the extraction of solid minerals, $24 \%$ in engineering and $19 \%$ in instrumentation (including defense industry enterprises) [9].

However, the capitalization of Russian state-owned companies in recent years has been significantly reduced. So, for 2010-2014 the value of shares of Russian state-owned companies decreased by $\$ 80$ billion. The average capitalization of state-owned oil and gas companies in 2017 amounted to $\$ 33$ billion (in 2007 - $\$ 82$ billion), and the transport sector - $\$ 1.5$ billion (in 2007 - $\$ 3.3$ billion) [10].

The problem of the gap of the Russian state from investing in a green economy, along with a reduction in its investment opportunities, actualizes the development of technological platforms and the formation of a special platform for sustainable development. Namely, it should become the basis for the reproduction of industrial capital on the basis of the innovative technological base necessary for sustainable development.

The priority area for the application of an "active" environmental policy in relation to sustainable development in Russia should be technological support for the restoration of the manufacturing industry [11]. The problems of the links between science and production, their state support was announced back in 2006 in the Russian Federation's Ministry of Science and Education's Development in 2006 the Forecast of the Scientific and Technological Development of the Russian Federation for the Long Term and the Concept for the LongTerm Forecast of the Scientific and Technological Development of the Russian Federation for the Period Until 2025 year [12].

\section{Results and Discussion}

We believe that the limited participation of Russian technology platforms in the transition to sustainable development is caused by the deviation of their tasks and functions from the original concept formulated for EU technology platforms that have proven their effectiveness.

The very principle of the formation of technological platforms in European countries is "bottom-up", that is, the main initiative belongs to enterprises, universities and scientific organizations, while the role of the state entity - the European Commission - is significantly limited. In Russia, technological platforms are formed at the initiative of the federal government and are controlled by it. Universities are recipients of state funding, and the interests of industrial enterprises are not sufficiently taken into account.

The goals of creating technology platforms in the European Union are to harmonize the economic interests of business firms and research and innovation organizations, as well as universities in the field of financing basic and applied research. The main goal of creating technology platforms in Russia is to attract state funding for R\&D organizations. This determines the main source of their financing in the EU countries - private investment and 
self-financing; in Russia - budget financing, loans of the Russian Venture Company and ROSNANO [13].

In accordance with these goals, the tasks assigned to technology platforms in the European Union and Russia are also different. The former are characterized by the development and implementation of strategies for promoting innovative products in the European and world markets, while the latter are characterized by performing expert functions for the government in supporting priority industries.

Thus, technological platforms in the Russian economy do not fulfill their main role initiating the transfer of innovations from state research institutes and universities to private and joint-stock industrial enterprises producing products of the high degree of processing to replace raw material export. We attribute this to the fact that the state, in spite of the dominant position in financing innovation in Russia, today lacks mechanisms that can coordinate the interests of the state in restoring the manufacturing industry - the foundations of the economy of modern industrial countries and filling the budget with non-resource revenues, the interests of scientific organizations, universities, technology parks for the introduction of mass production of innovations, as well as the interests of industrial enterprises to modernize production.

On the contrary, in the EU countries, "National Support Groups" of technology platforms are being created, bringing together leading scientists and officials who provide technological breakthroughs in high-tech industries, the deployment of new areas of diversification and advanced processing of raw materials, the formation of new sectors of the economy by overcoming the fragmentation of science and lack of structured interests of business [14-15].

We see neo-industrial business groups as subjects of platform integration designed to step up the transition to sustainable development. By them we mean the large industrial structures of recombined property (cross-ownership of enterprises by each other with the presence of the state) and unrelated (diversified) diversification.

Given the characteristics of large Russian holdings - the main national investors - such as the vertical nature and the classical type, a high degree of connection with the raw materials extraction and a recombined type of ownership, it is advisable to develop such business groups on the basis of public-private partnerships for sustainable development.

Neo-industrial business groups should integrate subsoil resource extraction and deep processing, research and innovation, logistics companies, whose joint activity is able to recreate large elements of the green economy production chains in the Russian economy. In contrast to public-private partnerships created in individual sectors, neo-industrial business groups must combine holdings and independent companies of several related industries on the basis of a strategic alliance. The mechanism of its formation assumes mutual parity investment of its participants in order to prevent the loss of ownership by owners of their assets and at the same time ensure coordination of investment, innovation, production and marketing activities.

The interests of Russian industrial companies in integrating into neo-industrial business groups must be in obtaining tax benefits, investment financing and access to new technologies. Therefore, the role of the state in stimulating such integration processes is to guarantee the ownership rights of members of business groups, their long-term credit support and tax benefits for investments in the development and transfer of mass production of innovations for the green economy, in the transfer of technologies from the defense industry, as well as investment in the creation of new environmentally friendly industries. We have proposed the following forms of government stimulation of innovation and production activities of neo-industrial business groups: preferential long-term lending to innovative projects for the development of the green economy in industries with the highest foreign competition; state co-investment in basic research in the framework of innovative projects; 
anti-crisis support for companies producing environment friendly products for the Russian market, provided that they enter neo-industrial business groups.

\section{Conclusion}

Thus, the initiation of the transition to sustainable development in Russia is closely related to the modification of economic relations in the reproduction system. These economic relations are associated with investing in the modernization of industry on an innovative technological basis, with an increase in the production of tangible and intangible goods in the framework of the green economy. The reproductive conditions for the transition to sustainable development include the formation of its technological platform and neoindustrial business groups, support and stimulation of demand for products of the green industry, accelerated creation of the target social group necessary for its development.

\section{References}

1. V.V. Guzyr', Economics and Innovation Management, 4, 4-19 (2019) DOI: 10.26730/2587-5574-2019-4-4-19

2. E. A. Gasanov, Economics and Innovation Management, 2, 39-49 (2019) DOI: 10.26730/2587-5574-2019-2-39-49

3. E. V. Slesarenko, 4, 4-15 (2018) DOI: 10.26730/2587-5574-2018-4-4-15

4. E. V. Shavina, Economics and Innovation Management, 3, 4-13 (2019) DOI: 10.26730/2587-5574-2019-3-4-13

5. O. Kalenov, S. Kukushkin, R. Kamanina, E3S Web Conf., 105, 04028 (2019)

6. S. Kukushkin, O.Kalenov, E3S Web Conf., 105, 04022 (2019)

7 M.S. Zlotnikov, V.V. Telnykh, S.I. Mutovin, S.K. Demchenko, J.J. Suslova, Journal of Environmental Management and Tourism, 8:2, 366-372 (2017)

8. K. Dugan, New York Post, 260, 11 (2014)

9. S. K. Demchenko, M. S. Zlotnikov, T. A. Melnikova, O. S. Demchenko, International Journal of Civil Engineering and Technology, 10:2, 1877-1884 (2019)

10. M. Cehlár, K. Čulková, H. Pavolová, S. Khouri, E3S Web Conf., 105, 04038 (2019)

11. F. N. Abu-Abed, D. V. Martynov, A. V. Ivanova, R. V. Dopira, R. Y. Kordyukov, ARPN Journal of Engineering and Applied Sciences, 11(16), 9636-9645 (2016)

12. F. Abu-Abed, A. Khabarov, E3S Web Conf., 41, 01028 (2018)

13. S. K. Demchenko, J. J. Suslova, A. S. Yamschikov, I. R. Ruyga, T. A. Melnikova, Journal of Applied Economic Sciences, 12:1, 194-205 (2017)

14. E. Dotsenko, N. Ezdina, E3S Web Conf., 41, 04048 (2018)

15. E. Dotsenko, N. Ezdina, S. Mudrova, E3S Web Conf., 41, 04050 (2018) 